\title{
The Dynamics of the Canadian Insurance Market Under NAFTA ${ }^{1}$
}

\author{
V. Demchuk
}

Valentina Demchuk - PhD student, Moscow State Institute of International Relations of the Ministry of Foreign Affairs of Russia; 76 Av. Vernadskogo, Moscow, 119454, Russian Federation; E-mail: valdemchuk@gmail.com

\begin{abstract}
This article analyses changes in quantitative indicators of the development of the insurance market in Canada within the framework of the North American Free Trade Agreement (NAFTA). The development of the world economy leads to the growing influence of economic integration, including integration in the insurance sector. Globalization makes it necessary for countries to work together to improve the stability of national financial systems. Along with the positive effects of integration, such as higher trade volumes, there are also negative repercussions, such as local producers being driven out of the market. The effects and risks associated with the influence of integration groups, identified in the course of research and discussions in economics, can be verified (or falsified) empirically on the basis of data on the development of national insurance markets within the framework of integration groups. Based on statistical data, econometric models were built to determine the effect of NAFTA on the Canadian insurance market by assessing the extent to which the changes in quantitative indicators of the development of the insurance market in Canada, namely the premium volume, insurance density and penetration, are due to the agreement. Based on existing insurance market research, a number of economic and social factors were selected as macroeconomic parameters affecting the premium volume. The author concludes that being a member of NAFTA does not affect the selected quantitative insurance development indicators in Canada. The author assumes this to be one of the reasons why the main NAFTA clauses concerning insurance were not significantly revised under the new United States-Mexico-Canada Agreement (USMCA). ${ }^{2}$
\end{abstract}

Key words: Canada; NAFTA; integration; insurance market; insurance premium; insurance density; insurance penetration

For citation: Demchuk V. (2019) The Dynamics of the Canadian Insurance Market Under NAFTA. International Organisations Research Journal, vol. 14, no 1, pp. 113-125 (in English). DOI: 10.17323/19967845-2019-01-07

In the context of globalization there is a need for cooperation between countries to increase the stability of national financial systems. Membership in integration associations has a positive impact on economies of all member countries due to the increase in multilateral trade volume, lower prices for a number of goods and services, wider range of consumer choice, incentives for innovation (as a result of higher competition) and

${ }^{1}$ The editorial board received the article in April 2018.

${ }^{2}$ At the time this article was written, negotiations were underway to amend the NAFTA, and at the time of its submission to the editor, a new agreement had been reached and signed in November 2018. 
access to new markets. Nevertheless, integration can have negative consequences as not all countries receive the same benefits from these processes. Among the negative consequences are the trade diversion effect, the displacement of national producers from the market and the imposition of "rules of the game" by relatively more-developed countries to relatively less-developed ones. Moreover, not all countries benefit equally from integration processes. A trade agreement between countries with different levels of development has a heterogeneous effect on the economies of its members.

Insurance markets are adapting to a single regime of trade in insurance services, which is formed depending on national and regional economic development strategies. At the same time, it should be noted that the strategy a member country chooses is based on the comparison of the level of economic development of the country with the level of development of other member countries. The fact that a "stronger" member may impose its own "rules of the game," as well as the possibility of stagnating or even declining production in some sectors are potential repercussions to be taken into account by relatively less-developed member countries. The European Union's insurance market has shown that not all countries benefit equally from integration [Pisarenko, Kuznetsova, 2014]. According to a number of scholars, for example G. V. Chernova, under certain conditions ${ }^{3}$ the positive effects of integration for the insurance market of every country outweigh the negative ones [2013]. In light of this, the development of insurance markets of NAFTA members is of particular interest, as it is a group of countries with different levels of development, ${ }^{4}$ the model of relations between which is sometimes described as "hub-and-spokes."

The North American Free Trade Agreement (NAFTA) came into force on 1 January 1994. It has recently been replaced by the United States-Mexico-Canada Agreement (USMCA ${ }^{5}$ ) signed by the three countries on November 30th $2018^{6}$ and coming into force in 2020. In the sphere of trade in financial services, the agreement stipulates that there is to be a national treatment and a most favoured-nation treatment for the member countries: "Each Party shall accord to investors of another Party treatment no less favorable than that it accords to its own investors" [NAFTA, 1992, Art. 1405], and "Each Party shall accord to investors of another Party, financial institutions of another Party... treatment no less favorable than that it accords to the investors... of any other Party or of a non-Party" [NAFTA, 1992, Art. 1406]. Financial service providers may establish a commercial presence in other countries, with the exception of the restrictions listed in the annex to the agreement.

\footnotetext{
${ }^{3}$ For example, when the level of development of the national insurance market is lower than the regional one.

${ }^{4}$ U.S. GDP per capita was $\$ 57,797$ in 2016 and only $\$ 18,535$ in Mexico (the figure for Canada is $\$ 44,819$ ).

Source: OECD [c. a., b].

${ }^{5}$ It should be noted that in Canada the Agreement is referred to as the Canada-United States-Mexico Agreement (CUSMA) or Accord Canada-États-Unis-Mexique (ACEUM) in French, while being referred to as Tratado entre México, Estados Unidos y Canadá (T-MEC) in Mexico.

${ }^{6}$ A new Canada-United States-Mexico Agreement, Government of Canada. Available at: https://www. international.gc.ca/trade-commerce/trade-agreements-accords-commerciaux/agr-acc/cusma-aceum/index. aspx?lang=eng (accessed 30 January 2019).
} 
Although quantitative restrictions agreed upon by the parties are allowed under the agreement [NAFTA, 1992, Annex VII], ${ }^{7}$ it is also stated that such restrictions should be revised or abolished in the future to facilitate integration. For example, a Canadian insurer, other than a life insurer or a reinsurer, could not purchase reinsurance services worth more than $25 \%$ of the risk undertaken by the insurer from a non-resident reinsurer under the initial agreement. This restriction was abolished in 2011, which led to more risks being transferred by Canadian insurers to non-Canadian reinsurers. Nevertheless, certain restrictions can still be imposed, for instance to protect investors, financial market participants and policyholders or to ensure the stability of a party's financial system [NAFTA, 1992, Art. 1410].

Due to changes in the geopolitical situation as well as in the economic landscape of the world, NAFTA member countries came to a new trade agreement - the USMCA, - on 30 September 2018 (after the formal deadline for the negotiations). The proclaimed grounds for amending the agreement on behalf of the United States were, first, that changes have occurred over the last 25 years that were not taken into account when the original NAFTA was signed, and second, that support should be provided for United States' workers [Lobosco, Borak, Luhby, 2018]. Changes to the existing agreement are mainly concerned with trade in goods, e.g. higher quotas of American dairy products in the Canadian market, lower share of car parts made outside North America in order for them to be exempt from tariffs (rules of origin) and a requirement that at least $30 \%$ (to rise to $40 \%$ in a few years) of car parts be made by workers earning no less than $\$ 16$ an hour. It also regulates spheres that are relatively new or which began developing rapidly after the agreement came into force, such as the digital economy and intellectual property rights.

It is worth noting that the new agreement elaborates more on the financial services sector, including insurance. The general provisions on the national and most-favourednation treatment (Art. 17.3 and Art. 17.4 of the USMCA, respectively) will not undergo significant changes. The possibility of imposing restrictions in order to protect investors, depositors and policyholders also remains (Art. 17.11). The reservations under this agreement for each country are set out in Annex III. For example, Mexican citizens cannot insure credit, housing credit and third party liability with foreign entities unless they can prove that "none of the insurance institutions authorized to operate in Mexico is able or deems convenient to enter into a given insurance operation proposed to it" [Office of the United States Trade Representative, 2018, Annex III: Mexico, Section A-9, p. ii].

The assessments of the effect of NAFTA on the welfare of member countries range from positive [Curtis, Sydor, 2006; Komkova, 2015; Caliendo, Parro 2015] to neutral ("without the NAFTA, the development of the country would be the same") [Romalis, 2007; Castaneda, 2014]. There are also studies devoted to analyzing the impact of this agreement on the insurance markets of member countries. For instance, various North American insurance associations (the American Insurance Association, the Insurance Bureau of Canada, the Mexican Association of Insurance Companies and several

${ }^{7}$ For instance, aggregate foreign investments in Mexican insurance companies must not exceed 50\% of paid-in capital. 
others) have expressed their positive view of NAFTA and support for the modernization of the agreement [Insurance Journal Staff, 2017]. Among the positive influences are:

- higher trade volumes

- wider customer choices

- expansion of the range of services provided

- facilitation of "cooperation among policymakers, regulators and insurers in all three countries"

- promotion of competition

- creation of "a regulatory environment that supports innovation, market efficiency and regulatory transparency"

Apart from the increase in trade in services, these associations mainly note qualitative impacts on the insurance markets of member countries.

A quantitative assessment of the impact of the agreement on the quantitative indicators of the Canadian insurance market can help evaluate how integration influences the insurance markets of the countries involved. Among the effects expected from integration in the services markets (as noted above) is higher competition, to which domestic insurance companies respond by increasing productivity, leading to lower insurance premiums and custom made products. If we observe an increase in trade in services as well as wider consumer choices, it can be assumed that total premium volumes will also grow despite slightly lower premiums as there will be higher demand. It must be noted that assessing the effects of NAFTA on the efficiency of insurance companies in member countries as well as estimating the welfare effects fall outside of the scope of this study and will be dealt with in future research.The choice of the country is based on the fact that, while both countries are developed, certain development indicators are lower in Canada than they are in the United States, such as gross domestic product (GDP) per capita $(\$ 44,773$ in Canada versus $\$ 59,495$ in the United States in 2017) [IMF, 2017]. In absolute numbers, the size of the Canadian economy is significantly smaller than the U.S. economy, as U.S. GDP at current prices in 2016 was 12 times higher than the GDP of Canada [IMF, 2017]. At the same time, both Canada and the U.S. are among the top-ten countries in the world in terms of gross insurance premium volume, while Mexico, the third NAFTA member, ranks 25th [Swiss Re Institute, 2017]. The total premium volume of NAFTA member countries is $\$ 1,491,311$ [Swiss Re Institute, 2017], of which $91 \%$ is collected in the United States and only $1 \%$ in Mexico. The data are shown in Table 1.

Table 1. Select Data on the NAFTA Insurance Market

\begin{tabular}{|l|c|c|c|c|c|}
\hline \multicolumn{1}{|c|}{ Country } & $\begin{array}{c}\text { Premium Volume } \\
\text { (\$ Million) }\end{array}$ & $\begin{array}{c}\text { Penetration } \\
\text { (Premiums as a \% of GDP) }\end{array}$ & Rank & $\begin{array}{c}\text { Density } \\
\text { (\$ per capita) }\end{array}$ & Rank \\
\hline U.S. & 1352385 & 7.49 & 16 & 4174.1 & 10 \\
\hline Canada & 114523 & 7.32 & 15 & 3161.1 & 19 \\
\hline Mexico & 24403 & 2.34 & 55 & 189.4 & 59 \\
\hline Total & 1491311 & 7.1 & - & 3049 & - \\
\hline
\end{tabular}

Source: Swiss Re Institute [2017]. 
In order to estimate the effect of integration on the quantitative indicators of insurance market development the following specification of the linear regression model was used:

$$
\begin{gathered}
y_{t}=\beta_{0}+\beta_{1} \text { GDPd }+\beta_{2} \text { InGrd }+\beta_{3} \text { Inf }+\beta_{4} \text { IntR }+\beta_{5} \text { Popd }+\beta_{6} \text { EmpRd }+\beta_{7} \text { Unempd }+ \\
\beta_{8} \text { PovR }+\beta_{9} \text { NAFTA }+\varepsilon_{t}=\beta_{0}+X_{i t} \beta,
\end{gathered}
$$

where $y_{t}$ is the dependent variable (gross premium (GrossPrd), density (Den) and penetration (Pen) respectively in the three models), $x_{i t}$ are the control variables detailed bellow, $\beta_{0}$ is the intercept $\beta_{i}$ are the coefficient of the explanatory variables and $\varepsilon_{t}$ is the error term. For the purposes of this analysis, the author assumes that the relation between the gross premium (or, to be more precise, the change in the gross premium) is linear and not quadratic.

Explanatory variables were chosen based on factors that have an effect on gross premiums identified in existing studies. These factors can be divided into four groups [Golysheva et al., 2016]. The first group includes economic factors. Insurance contributes to the redistribution of cash flows as insurance funds - formed out of insurance premiums and thus connected with the income of citizens and working capital of enterprises - are subsequently invested in the economy. Shortage of working capital along with low incomes of the population are factors that hinder the development of the insurance market.

The second group includes political factors that characterize the political stability in a country and government policy in insurance. It should be noted that there is political stability in Canada, and despite a number of changes in insurance legislation, these changes do not have a significant effect on the premium volume and therefore this group of factors will not be taken into account in the model.

The third group can be defined as social factors, that is macroeconomic indicators having to do with demographics, consumer preferences, cultural traditions and financial literacy. Urbanization also affects the insurance market since urban dwellers are the principal consumers of insurance services.

The last group includes technological factors, which have a growing influence on the insurance market: online insurance, electronic sales of insurance policies and the use of new technologies by insurance companies. These factors increase the availability of insurance services and reduce the costs of running an insurance company, but there are also risks associated with the use of technology, such as hacking and data loss.

The observation period is from 1984 to 2016, the data are annual and there is a total of 33 observations of 10 variables. The data are from the Organisation for Economic Co-operation and Development (OECD) website. The data are somewhat inconsistent with the data in the Sigma journal (Swiss Re). Due to the fact that to estimate an econometric model it is necessary to work with stationary time series (otherwise there is a chance to get a so-called "spurious regression"), the first logarithmic difference of non-stationary time series was taken. This difference corresponds to the percentage change in these indicators (series with the logarithmic difference are marked with the letter " $d$ " at the end of the variable name). 
The following explanatory variables were selected for the analysis:

Table 2. List of Explanatory Variables in the Model

\begin{tabular}{|l|l|}
\hline GDPd & first logarithmic difference of GDP per capita (in \$) \\
\hline InGrd & first logarithmic difference of gross fixed capital formation (annual growth rate in percent) \\
\hline Inf & inflation rate (calculated based on the Consumer Price Index (CPI) \\
\hline IntR & long-term interest rates on government bonds maturing in 10 years \\
\hline Popd & first logarithmic difference of population \\
\hline EmpRd & first logarithmic difference of the employment rate (as a percentage of working age population) \\
\hline Unempd & first logarithmic difference of the unemployment rate \\
\hline PovR & poverty (ratio of people whose income falls below the poverty line to total population) \\
\hline NAFTA & binary variable that equals 1 starting in 1994, when NAFTA came into force \\
\hline
\end{tabular}

Source: compiled by author.

GDP per capita was chosen as an explanatory variable because at the end of the 20th century it was demonstrated that the growth rate of insurance penetration is correlated with GDP per capita rather than simply the GDP of a country. According to this theory, developed by G.M. Dickinson, R.L. Carter and R. Enz [Carter, Dickinson, 1992; Enz, 2000], penetration increases as GDP per capita rises. However, after GDP per capita reaches a relatively high level, insurance penetration stops growing, so the increase in insurance penetration is no longer correlated with the increase in GDP per capita. The graphic interpretation of this relationship has the shape of the letter "S," which is why the name of the model is "S-curve."

Investment has an impact on insurance premiums because legal entities account for a high share of demand for insurance. Investment is a leading indicator of output and contributes to higher production capacity, the increase of which leads to a higher value and/or quantity of objects insured.

The inflation rate, as well as interest rates, mostly influence customers' decisions to purchase life insurance, as well as the overall level of consumer confidence. Interest rates also affect the volume of loans and, by extension, insurance premiums, since insurance contracts are often required in order to get a loan (life insurance in case of mortgages and/or insurance of property bought on credit or used as collateral).

The effect of population on premium volume is intuitively understandable, while the levels of employment, unemployment and poverty characterize the social situation in the country and determine the level of effective demand.

The dummy (binary) variable "NAFTA," which equals 0 up until 1993 and 1 starting 1994, was selected to estimate the impact of joining NAFTA on the quantitative indicators of insurance market development in Canada. NAFTA can affect the premium volume and other indicators in various ways. For example, due to the increased trade volume resulting from lower trade barriers there is a need to insure more cargo. Higher 
competition, on the contrary, will lead to lower prices and consequently to a decrease in the premium volume. This binary variable works to incorporate these changes.

The fact that these indicators have an effect on the premium volume is confirmed by the correlation between these indicators and the premium volume. Using $\mathrm{R}$, the effect of all of the above factors on the gross insurance premium was estimated, and at a significance level of $10 \%$ the statistically significant factors are the following explanatory variables: inflation and employment rate. Statistically insignificant variables were gradually excluded from the model until all coefficients were significant (the critical t-value is 1.699) and had a statistically significant impact on the premium volume.

To check model adequacy, a correlation matrix of explanatory variables was built (a strong correlation was found between changes in investment volumes, GDP and the unemployment rate (over 0.7 ), as well as between inflation and interest rates (which is in line with the Fisher equation, according to which the nominal interest rate is adjusted for inflation so that the real interest rate remains unchanged). Models were also tested for heteroscedasticity and autocorrelation of residuals using the Breusch-Pagan and Box-Ljung tests, respectively. According to these tests, there is no heteroscedasticity or auto-correlation of residuals in any of the models.

The initial and final models of the relationship between the gross premium and selected factors are shown in Table 3.

Table 3. Models for Estimating the Relationship Between Gross Premium and Selected Macroeconomic Indicators

\begin{tabular}{|l|c|c|c|c|c|c|}
\hline \multirow{2}{*}{ Model Number } & Coefficient & $\operatorname{Pr}(>|t|)^{1}$ & Coeff. & \multicolumn{1}{c|}{$\operatorname{Pr}(>\mid \mathbf{t})$} & Coeff. & $\operatorname{Pr}(>\mid \mathbf{t})$ \\
\cline { 2 - 7 } & \multicolumn{2}{|c|}{1} & \multicolumn{2}{c|}{2} & \multicolumn{2}{c|}{3} \\
\hline Dependent Variable & \multicolumn{2}{|c|}{ GrossPrd } & \multicolumn{2}{c|}{ GrossPrd } & \multicolumn{2}{c|}{ GrossPrd } \\
\hline Const & 0.070504 & 0.9267 & -0.06942 & 0.89933 & -0.09298 & 0.03763 \\
\hline GDPd & 3.021698 & 0.1420 & 2.48783 & 0.06333 & 1.60397 & 0.09540 \\
\hline EmpRd & 8.496636 & 0.0322 & 9.57092 & 0.00953 & 10.42162 & 0.00114 \\
\hline InGrd & 0.010747 & 0.9883 & - & - & - & - \\
\hline Popd & -7.368092 & 0.4077 & -0.52616 & 0.94211 & - & - \\
\hline Unempd & 0.394522 & 0.3024 & 0.30073 & 0.36382 & - & - \\
\hline Inf & 0.051147 & 0.0372 & 0.04566 & 0.04882 & 0.02619 & 0.07273 \\
\hline PovR & -1.994805 & 0.7178 & -1.29939 & 0.75923 & - & - \\
\hline IntR & -0.001425 & 0.9300 & - & - & - & - \\
\hline NAFTA & 0.099156 & 0.2519 & 0.10211 & 0.14566 & - & - \\
\hline$R^{2}$ & \multicolumn{2}{|c|}{0.6403} & \multicolumn{2}{c|}{0.6279} & & - \\
\hline Adjusted R ${ }^{2}$ & \multicolumn{2}{|c|}{0.4932} & & \multicolumn{2}{c|}{0.5193} & \\
\hline
\end{tabular}

Source: author's calculations in R.

${ }^{1}$ Where applicable. 
Based on the estimated models, it is clear that GDP per capita, the level of employment and the rate of inflation have an effect on the premium volume. The coefficient of determination $\left(\mathrm{R}^{2}\right)$ of the final model is 0.5805 , which means that the selected factors explain only $58 \%$ of the variation in the dependent variable. However, an $\mathrm{R}^{2}$ greater than $50 \%$ is considered acceptable, so the model can potentially be used to predict the gross premium. According to these estimates, NAFTA membership did not contribute to the growth of gross premiums.

Figure 1 shows the actual and fitted values of the changes in the gross premium volume in Canada between 1985-2016.

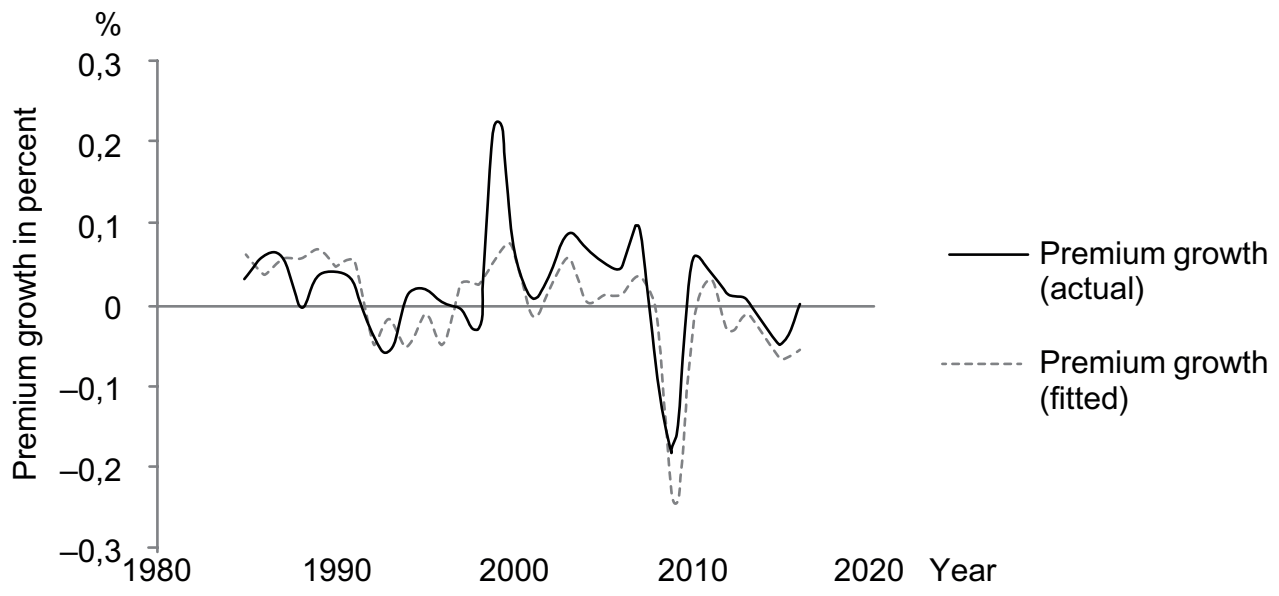

Fig. 1. Actual and Fitted Values of the Changes in the Gross Premium Volume in Canada, 1985-2016

Source: Plotted by the author based on OECD data: Insurance Indicators (c. a., c) and the model estimates obtained in $\mathrm{R}$.

Available at: https://stats.oecd.org/Index.aspx?DatasetCode=INSIND.

Since the 2000s, gross premium volume increased (positive growth rates), but it later decreased as a result of the financial crisis. Note that the crisis also had a negative impact on insurance density and penetration, which can be seen in Fig. 2.

The ratio of insurance premiums to GDP remained around 4-6\% starting 1984 until the last few years of the century when it began to grow steadily, peaking at almost $8 \%$ before the financial crisis and then decreasing to around $5 \%$. These data suggest that the reduction in premiums was greater than the reduction in GDP, meaning the insurance market is more sensitive to crises and shocks than the economy in general.

The changes in insurance density in Canada are similar to that of the gross premium. This is due to the fact that the population of Canada has been growing steadily over the past 20 years, albeit at a slow pace: since 1992 the maximum growth rate has not exceeded $1.2 \%$ (in 1986-1990 population growth rates reached $1.8 \%$ ). Thus, the change in population size slightly "smoothes out" the fluctuations of insurance density compared to changes in premium volume. 


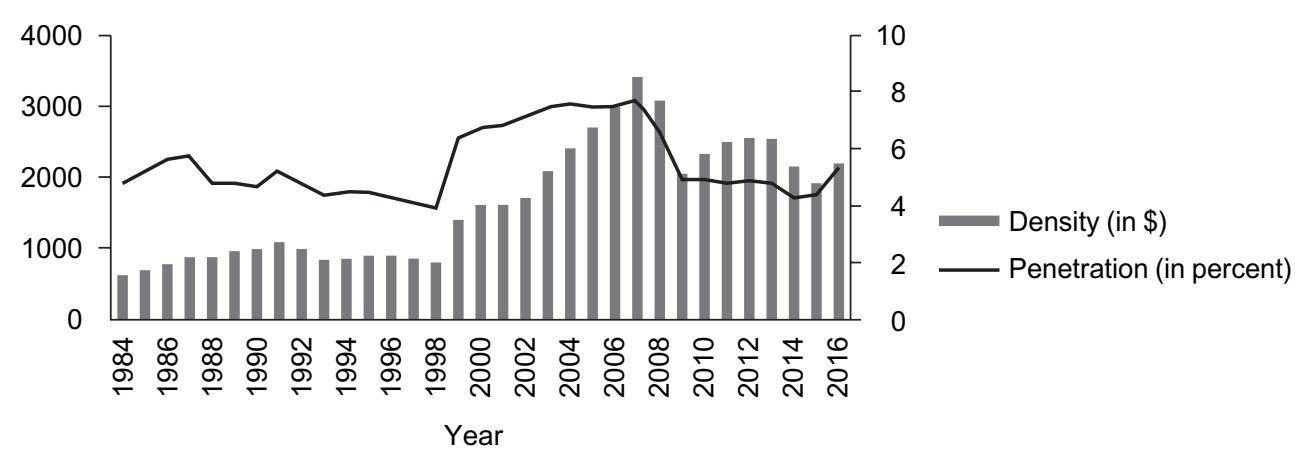

Fig. 2. Insurance Density and Penetration in Canada, 1984-2016

Source: OECD data: Insurance Indicators (c. a., c.)

Available at: https://stats.oecd.org/Index.aspx?DatasetCode=INSIND.

Based on the same assumptions and the same methods used when building models to determine the relationship between premium volume and NAFTA membership, the effect of being a part of NAFTA on the density and penetration of insurance in Canada was estimated. The results are shown in Table 4.

Table 4. Models for Estimating the Effect of Macroeconomic Indicators on Insurance Density and Penetration

\begin{tabular}{|l|c|c|c|c|c|c|c|c|}
\hline & Coeff. & $\operatorname{Pr}(>|t|)^{2}$ & Coeff. & $\operatorname{Pr}(>|t|)$ & Coeff. & $\operatorname{Pr}(>|t|)$ & Coeff. & $\operatorname{Pr}(>|t|)$ \\
\hline Model Number & \multicolumn{2}{|c|}{4} & \multicolumn{2}{c|}{5} & \multicolumn{2}{c|}{6} & \multicolumn{2}{c|}{7} \\
\hline $\begin{array}{c}\text { Dependent } \\
\text { Variable }\end{array}$ & \multicolumn{2}{|c|}{ Pen } & \multicolumn{2}{c|}{ Pen } & \multicolumn{2}{c|}{ Den } & \multicolumn{2}{c|}{ Den } \\
\hline Const & 0.567666 & 0.31708 & 4.705 & 0.03812 & -34.403 & 0.4829 & 21.5678 & 0.0146 \\
\hline GDPd & -0.555092 & 0.67495 & - & - & -131.013 & 0.3135 & - & - \\
\hline EmpRd & 10.041521 & 0.00807 & 40.671 & 0.00245 & -143.850 & 0.5387 & - & - \\
\hline InGrd & - & - & - & - & 35.210 & 0.4494 & - & - \\
\hline Popd & -0.784731 & 0.91571 & -72.418 & 0.03528 & - & - & - & - \\
\hline Unempd & 0.157675 & 0.63956 & - & - & -51.326 & 0.0355 & -31.4329 & 0.0304 \\
\hline Inf & 0.008138 & 0.72087 & - & - & -3.000 & 0.0480 & -3.5241 & 0.0167 \\
\hline PovR & -4.893817 & 0.26510 & -32.590 & 0.05194 & 401.451 & 0.2632 & - & - \\
\hline IntR & - & - & - & - & 2.728 & 0.0146 & 1.67188 & 0.0305 \\
\hline NAFTA & 0.038061 & 0.58886 & - & - & -7.215 & 0.1979 & -9.5456 & 0.0729 \\
\hline$R^{2}$ & \multicolumn{2}{|c|}{0.3892} & \multicolumn{2}{|c|}{0.3525} & 0.5942 & & 0.5177 \\
\hline Adjusted R ${ }^{2}$ & 0.2111 & \multicolumn{2}{|c|}{0.3062} & 0.453 & & 0.4463 \\
\hline
\end{tabular}

Source: Author's calculations in R.

${ }^{2}$ Where applicable. 
Note that for estimating the effect of NAFTA on density, population growth was excluded from the models because population size is used to calculate insurance density.

Based on these models, it can be said that the employment rate, poverty and population growth are factors that have an effect on penetration. In this study, these variables describe effective demand. It must be noted that these factors only explain $35 \%$ of the variance of penetration, thus it is necessary to take other indicators into account to predict the penetration. The estimated model is in line with the "S-curve" because in this case GDP per capita is so high that its increase has no effect on insurance penetration.

At a $10 \%$ significance level, being a member of NAFTA (along with unemployment, inflation and interest rates) does have a non-zero effect on insurance density. Thus, based on this estimate we can say that the insurance premium per capita, other things being equal, has decreased as a result of Canada becoming a member of NAFTA. This is partly because of higher competition driving prices down as a result of U.S. companies penetrating the Canadian market. It may also be due to the fact that with higher volumes of trade some companies switched to insuring foreign trade with insurers from the United States rather than Canada. It is worth noting, however, that a significance level of $5 \%$ or below is usually set in econometric analysis, so we can say that being a member of NAFTA has no effect on the indicators of the development of the Canadian insurance market examined in this study.

This article concludes that GDP per capita (the main indicator of economic development), the employment rate (one of the factors determining effective demand) and the inflation rate have an effect on gross premiums in Canada. Insurance penetration, in turn, is affected by population growth, as well as employment and poverty. Finally, the insurance density in Canada, according to the estimated models (at a significance level of 5\%) is influenced by the unemployment rate, the inflation rate and the long-term interest rates on government bonds maturing in 10 years. At the same time, NAFTA does not have a significant effect on these quantitative indicators of the development of the Canadian insurance market. In light of this, as well as the fact that the Canadian insurance market is quite small for the United States in terms of volumes, ${ }^{8}$ it is understandable that the main provisions of NAFTA with regard to insurance markets were not considerably revised under the new agreement.

\section{References}

Caliendo L., Parron F. (2015) Estimates of the Trade and Welfare Effects of NAFTA. Review of Economic Studies, vol. 82 (1), pp. 1-44.

Carter R., Dickinson G. (1992) Obstacles to the Liberalization of Trade in Insurance. London: Harvester Wheatsheaf, pp. 175-188.

${ }^{8}$ According to OECD data market share of foreign companies in the Canadian insurance market was $21 \%$ or $\$ 17.554$ million in 2015, which was $0.67 \%$ of total gross premiums in the United States in the same year (note that not only U.S. companies operate in the Canadian market). See OECD [c. a., c]. 
Castaneda J. (2014) NAFTA’s Mixed Record. Foreign Affairs, January - February, pp. 134-141.

Chenoa G.V. (2013) Globalizatsiya i vstupleniye Rossii v VTO - vazhneyshiye factory razvitiya rossiiskogo strakhovogo rynka na sovremennom etape [Globalization and Russia's Accession to the WTO: The Most Important Factors of the Russian Insurance Market Development at the Present Stage]. Finansy $i$ kredit, vol. 27, no 555, pp. 15-28. (In Russian)

Curtis J., Sydor A. (eds) (2006) NAFTA@10. Ottawa: Minister of Public Works and Government Services Canada.

Enz R. (2000) The S-Curve Relation Between Per-Capita Income and Insurance Penetration. Geneva Papers on Risk and Insurance: Issues and Practice, vol. 25, no 3, pp. 396-406.

Golysheva E., Speransky S., Tikhomirov S. (2016) Faktory razvitiya strakhovogo rynka: regional'ny aspect [The Factors of Environment Influencing on the Condition and Development of the Insurance Market: Regional Aspects]. Sovremennyye naukoyomkoye tekhnologii. Regionalnoye prilozheniye, no 1, pp. 16-21. Available at: www.isuct.ru/e-publ/snt/sites/ru.e-publ.snt/files/2016/01/snt_2016_n01-16.pdf (accessed 3 April 2018). (In Russian)

Insurance Journal Staff (2017) Insurance Associations Express Support for NAFTA. The Insurance and Investment Journal, 26 June. Available at: https://insurance-journal.ca/article/insurance-associationsexpress-support-for-nafta/ (accessed 3 April 2018).

International Monetary Fund (IMF) (2017) World Economic Outlook Database, October 2017: Canada, United States. Available at: www.imf.org/external/pubs/ft/weo/2017/02/weodata/weorept.aspx?sy=201 $6 \&$ ey $=2018 \& \mathrm{scsm}=1 \& \mathrm{ssd}=1 \&$ sort $=$ country $\& \mathrm{ds}=. \& \mathrm{br}=1 \& \mathrm{pr} 1 . \mathrm{x}=60 \& \mathrm{pr} 1 . \mathrm{y}=7 \& \mathrm{c}=156 \% 2 \mathrm{C} 111 \& \mathrm{~s}=\mathrm{NG}$ DP_R\%2CNGDPD\%2CPPPGDP\%2CNGDPRPC\%2CNGDPRPPPPC\%2CNGDPDPC\%2CLP\& grp $=0 \& a=($ accessed 3 April 2018).

Komkova E. (2015) 20 let NAFTA [20 Years of NAFTA]. Mirovaya ekonomika I mezhdunarodnyye otnosheniya, no 7, pp. 41-52. (In Russian)

Lobosco K., Borak D., Luhby T. (2018) What's New in the U.S., Canada and Mexico Trade Deal? CNN Business, 1 October. Available at: https://www.cnn.com/2018/10/01/politics/nafta-usmca-differences/ index.html (accessed 26 October 2018).

North American Free Trade Agreement (NAFTA) (1992) Available at: www.nafta-sec-alena.org/Home/ Texts-of-the-Agreement/North-American-Free-Trade-Agreement (accessed 3 April 2018).

Office of the United States Trade Representative (2018) United States-Mexico-Canada Agreement Text. Available at: https://ustr.gov/trade-agreements/free-trade-agreements/united-states-mexico-canadaagreement/agreement-between (accessed 17 December 2018).

Organisation for Economic Co-operation and Development (OECD) (c. a., a) Data. Available at: https://data.oecd.org/ (accessed 26 October 2018).

Organisation for Economic Co-operation and Development (OECD) (c. a., b) Gross Domestic Product. Available at: https://data.oecd.org/gdp/gross-domestic-product-gdp.htm (accessed 26 October 2018).

Organisation for Economic Co-operation and Development (OECD) (c. a., c) Insurance Indicators. Available at: https://stats.oecd.org/Index.aspx?DatasetCode=INSIND (accessed 26 October 2018).

Pisarenko Zh., Kuznetsova N. (2014) Regulirovaniye strakhovoi deyatel'nosti: uchebnik dlya bakalavriata I magistratury [Insurance Regulation: Textbook and Manual for Bachelor and Master Students]. Moscow: Yurait. (In Russian)

Romalis J. (2007) NAFTA's and CUSFTA's Impact on International Trade. Review of Economics and Statistics, vol. 89, no 3 (August), pp. 416-435.

Swiss Re Institute (2017) World Insurance in 2016: The China Growth Engine Steams Ahead. sigma, no 3/2017. Available at: http://media.swissre.com/documents/sigma3_2017_en.pdf (accessed 3 April 2018). 


\title{
Динамика страхового рынка Канады в условиях НАФТА ${ }^{1}$
}

\author{
В.А. Демчук
}

Демчук Валентина Артуровна - аспирант Московского государственного института международных отношений МИД России; 119454, Российская Федерация, Москва, просп. Вернадского, д. 76; E-mail: valdemchuk@gmail.com

Статья посвящена анализу изменений количественных показателей развития страхового рынка Канады в рамках действия Североамериканского соглашения о свободной торговле. Развитие мировой экономики происходит при возрастающем влиянии экономической интеграции, охватывающей все сферы экономической жизни, в том числе страховой сектор. Усиление процессов глобализации обуславливает необходимость сотрудничества стран для повышения устойчивости национальных финансовых систем. Наряду с положительными сторонами интеграции, такими как увеличение объема торговли, имеются и отрицательные, к примеру, вытеснение наииональных производителей с рынка. Кроме того, очевидно, что не все страны получают одинаковую выгоду от интеграционных процессов. Эффекты и риски, связанные с влиянием интеграционных объединений на национальные страховые рынки стран-участнии, выделенные в ходе исследований и дискуссий в экономической науке, могут быть верифицированы (или фальсифицированы) эмпирически за счет получаемых данных о развитии национальных страховых рынков стран в рамках интеграционных объединений и построения соответствуюших математических моделей. На основе статистических данных были построены эконометрические модели с целью выявления влияния Соглашения НАФТА на страховой рынок Канады путем оценки того, насколько изменения количественных показателей развития страхового рынка данной страны, а именно объема собираемых премий, плотности и проникновения страхования, связаны с действием Соглашения. В качестве макроэкономических параметров, влияющих на объем собираемых премий, в целях регрессионного анализа был отобран ряд экономических и социальных факторов, выделенных в ходе исследований страхового рынка. Автор приходит к выводу, что участие в данной интеграционной группировке не влияет на исследуемые количественные показатели развития страхового рынка Канады, и предполагает, что это одна из причин, по которой положения Североамериканского соглашения о свободной торговле в сфере страхования не были серьезно пересмотрены в рамках нового соглашения США - Мексика - Канада (USMCA) ${ }^{2}$.

Ключевые слова: Канада; НАФТА; интеграция; страховой рынок; страховая премия; плотность страхования; проникновение страхования

Для цитирования: Демчук В.А. (2019) Динамика страхового рынка Канады в условиях НАФТА // Вестник международных организаций. Т. 14. № 1. C. 113-125. DOI: 10.17323/1996-7845-2019-01-07

\section{Источники}

Голышева Е.Е., Сперанский С.Н., Тихомиров С.В. (2016) Факторы развития страхового рынка: региональный аспект // Современные наукоемкие технологии. Региональное приложение. № 1. C. 16-21. Режим доступа: www.isuct.ru/e-publ/snt/sites/ru.e-publ.snt/files/2016/01/snt_2016_n01-16.pdf (дата обращения: 03.04.2018).

Комкова Е. (2015) 20 лет НАФТА // Мировая экономика и международные отношения. № 7. С. $41-52$.

Писаренко Ж.В., Кузнецова Н.П. (2014) Регулирование страховой деятельности: учебник и практикум для бакалавриата и магистратуры. М.: Юрайт.

${ }^{1}$ Статья поступила в редакцию в апреле 2018 г.

${ }^{2}$ На момент написания статьи велись переговоры о реформировании НАФТА, на момент сдачи статьи в редакцию было достигнуто новое Соглашение, подписанное в ноябре 2018 г. 
Чернова Г.В. (2013) Глобализация и вступление России в ВТО - важнейшие факторы развития российского страхового рынка на современном этапе // Финансы и кредит. Т. 27 (555). С. 15-28.

Insurance Journal Staff (2017) Insurance Associations Express Support for NAFTA // The Insurance and Investment Journal. 26 June. Available at: https://insurance-journal.ca/article/insurance-associations-expresssupport-for-nafta/ (дата обращения: 03.04.2018).

Caliendo L., Parro F. (2015) Estimates of the Trade and Welfare Effects of NAFTA // Review of Economic Studies. Vol. 82 (1). P. 1-44.

Carter R., Dickinson G. (1992) Obstacles to the liberalization of trade in insurance. L.: Harvester Wheatsheaf. P. $175-188$.

Castaneda J. (2014) NAFTA's Mixed Record // Foreign Affairs. Jan. - Feb. P. 134-141.

Curtis J., Sydor A. (eds) (2006) NAFTA@10. Ottawa: Minister of Public Works and Government Services Canada.

Enz R. (2000) The S-Curve Relation Between Per-Capita Income and Insurance Penetration // Geneva Papers on Risk and Insurance - Issues and Practice. Vol. 25 (3). P. 396-406.

Lobosco K., Borak D., Luhby T. (2018) What's New in the U.S., Canada and Mexico Trade Deal? CNN Business. 1 October. Режим доступа: https://www.cnn.com/2018/10/01/politics/nafta-usmca-differences/index. html (дата обращения: 26.10.2018).

North American Free Trade Agreement (NAFTA) (1992) Режим доступа: www.nafta-sec-alena.org/Home/ Texts-of-the-Agreement/North-American-Free-Trade-Agreement (дата обращения: 03.04.2018).

Government of Canada (2018) A new Canada-United States-Mexico Agreement, Government of Canada. Режим доступа: https://www.international.gc.ca/trade-commerce/trade-agreements-accords-commerciaux/ agr-acc/cusma-aceum/index.aspx?lang=eng (дата обращения: 30.01.2019).

Organisation for Economic Co-operation and Development (OECD) (с. а., a) Database. Режим доступа: https://data.oecd.org/ (дата обращения: 26.10.2018).

Romalis J. (2007) NAFTA's and CUSFTA's Impact on International Trade // Review of Economics and Statistics. Vol. 89. No. 3. P. 416-435.

Office of the United States Trade Representative (2018) United States-Mexico-Canada Agreement Text. Режим доступа: https://ustr.gov/trade-agreements/free-trade-agreements/united-states-mexico-canada-agreement/ agreement-between (дата обращения: 17.12.2018).

International Monetary Fund (IMF) (2017) World Economic Outlook Database, October 2017: Canada, United States. Режим доступа: www.imf.org/external/pubs/ft/weo/2017/02/weodata/weorept.aspx?sy=2016\&ey $=2018 \& \mathrm{scsm}=1 \& \mathrm{ssd}=1 \&$ sort $=$ country $\& \mathrm{ds}=. \& \mathrm{br}=1 \& \mathrm{pr} 1 . \mathrm{x}=60 \& \mathrm{pr} 1 . \mathrm{y}=7 \& \mathrm{c}=156 \% 2 \mathrm{C} 111 \& \mathrm{~s}=\mathrm{NGDP} \_\mathrm{R} \% 2 \mathrm{C}$ NGDPD\%2CPPPGDP\%2CNGDPRPC\%2CNGDPRPPPPC\%2CNGDPDPC\%2CLP\&grp=0\&a= (дата обращения: 03.04.2018).

Swiss Re Institute (2017) World Insurance in 2016: The China Growth Engine Steams Ahead // Sigma. No 3. Режим доступа: http://media.swissre.com/documents/sigma3_2017_en.pdf (дата обращения: 03.04.2018). 